\title{
Sociological Analysis Of Domestic Child Labor
}

\author{
Sadia Barrech \\ Department of Social Work \\ University of Balochistan
}

\section{Muhammad Din}

Department of Sociology

International Islamic University Islamabad

\begin{abstract}
Allauddin
School of International Relations and Public Affairs Shanghai International Studies University
\end{abstract}

\begin{abstract}
A large number of children are engaged in child labour as domestic worker and this trend is common in developing countries. Child domestic labor is usually practiced in rural and urban areas across Pakistan. Even educated and well-to-do people frequently engage young children to work in their homes as domestics, kitchen assistants or baby-sitters. In worse forms, child domestic labor takes place over very unfair tools, counting child trafficking and bonded labor. The aim of the present study is to examine the Socio-economic characteristics of respondent's causes of child domestic labor. Universe of the study was Quetta city and 120 respondents were selected through snow ball sampling. According to findings of the study the child laborers work for longer hours on low wages. They often face physical abuse and some time sexual abuse by their employers. The need is to implement the labour laws so that children can be protected from domestic labour.
\end{abstract}

Keywords: Child Labor, Child Domestic Labor.

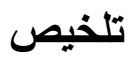

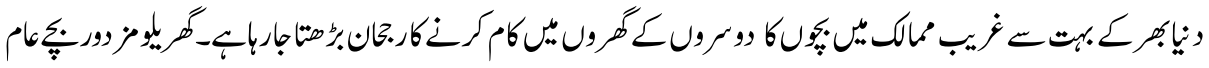

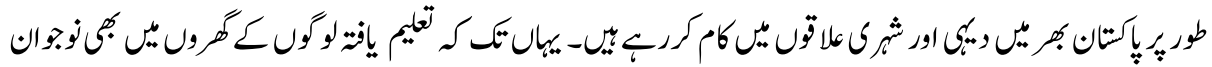

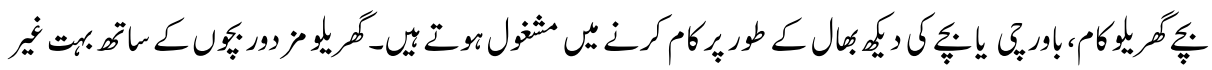

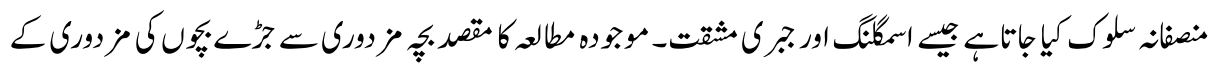

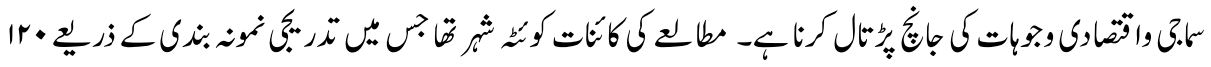

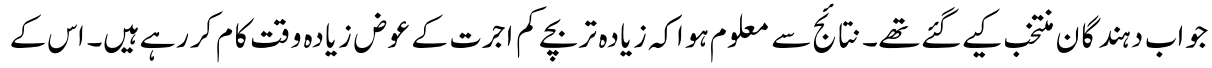




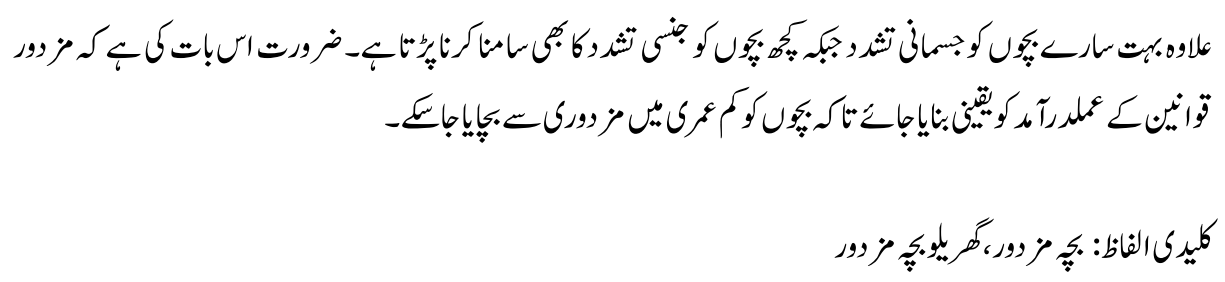

\section{Introduction}

Child Domestic Labor (CDL) refers to circumstances where children accomplish domestic responsibilities, not in their own home but rather in the home of an outsider or 'business' under abusive conditions. These children work away from public scrutiny in the protection of individuals' homes, this absence of perceptibility extraordinarily builds the probable for mistreatment and misuse (Maia \& Cal, 2014). When a child is inside a business' home, s/he is viably escaped opinion; bosses have all out command over their lives. This is a highhazard circumstance for the child. Violence and misuse (of various sorts) could occur in secret, ignored by the external world. Further recently, child domestic work is measured in numerous pieces of the world as a most exceedingly terrible type of child work, characterized by the ILO Convention 182. The Government of Pakistan confirmed Convention 182, in 2001. This ties the legislature to handle the matter of child work by overhauling enactments and creating fitting approaches and plans (d'Souza, 2010).

In South Asia, child domestic labor (CDL) is socially acknowledged and normally drilled. CDL alludes to circumstances where children are locked in to do domestic undertakings in the home of an outsider or manager. Where child domestic labor is abusive and incorporates dealing, servitude, or performs like subjugation, or work that, by its tendency or the conditions in that it is done, is dangerous and prone to hurt the wellbeing, security, or ethics of the child, it comprises a worst type of child labor as characterized in the International Labor Organization (ILO) Worst Forms of Child Labor Convention (Matsuno \& Blagbrough, 2006).

The Convention on the Rights of the Child perceives in Article 32 the privilege of the child "to be shielded from monetary abuse; and from some effort that is probably going to interfere with the child's exercise, or to be dangerous to the child's welfare or corporeal, psychological, ethereal, decent or communal development (Alderson, 2008). In actualizing this article, the CRC indicates that States ought to have "respect for the significant arrangements of other worldwide instruments," which alludes especially to the International Labor Office Conventions and Recommendations regarding the matter. In doing as such, the CRC hosts animated many State gatherings to likewise endorse the ILO Conventions on child labor and take authoritative activities so as to keep children from financial misuse (Thompson, 1992). Be that as it may, while laws managing the work of children have changed, change of labor arrangements has just tended to the circumstance of children working in the formal area. Change of labor arrangements has 
deserted the most undetectable child specialists: child domestic specialists. Since child domestic specialists are utilized inside a casual family condition they are not typically coordinated as a professional gathering inside conventional working frameworks since such reconciliation would assume an acknowledgment of the possibility of child domestic labor. In the meantime, since they are left without lawful insurance, it is hard to battle child domestic labor (Van Walsum, 2011).

In Pakistan, Child work is a genuine child rights just as an advancement matter. Child domestic work is rising as a progressively pervasive type of child work and is deceptive because of its imperceptibility. Children keep on being a wellspring of shabby work for families the nation over. This supposed commonly gainful plan has offered approach to commercialization of children's work and a progressively manipulative type of subjugation(Ali, Shahab, Ushijima, \& de Muynck, 2004). In a nation with $30 \%$ populace living underneath neediness line and a deprived open division training framework CDL will undoubtedly increment except if quick advances are occupied to reduce the issue(Bittman, England, Sayer, Folbre, \& Matheson, 2003). CDL is understood both in elite and non-elite homes and henceforth its developing inescapability. Anyway in Pakistan it has not been recognized as a most exceedingly awful structure in the rundown of 29 dangerous kinds of WFCL (annex) (Dennis, 1999). This is essentially because of the disposition of social acknowledgment of this type of child work whereby bosses deliberate and see it as a demonstration of kindness, however no alleviation counting instruction openings and diversion are accessible to these children. This public acknowledgment to CDL as a 'big-hearted' act to balance 'destitution' aggravates the issues and brands mediations hard to actualize and furthermore to continue. Also grownup domestic work is substituted with CDL which is undeniably increasingly sensible and unquestionably less expensive (Sadruddin, 2011).

Besides, the objective of widespread proficiency stays subtle and school dropout rates stay huge. In a perfect world, Pakistan ought to have a law overseeing domestic child labor, however domestic labor when all is said in done (Akhtar \& Razzaq, 2005). Tragically the Service of Children Act 1991 does not cover domestic child labor. Our politicians must demonstrate this will to act and take domestic child labor inside the domain of the law (Basu, 1999).

Child labor is a genuine child rights just as an improvement issue in Pakistan. Child domestic labor is rising as an increasingly pervasive type of child labor and is slippery because of its intangibility. Children keep on being a wellspring of modest labor for families the nation over. This supposed commonly valuable course of action has offered approach to work and a progressively unfair type of subjugation (Javaid, Arshad \& Khalid, 2011). In a nation with $30 \%$ populace existing beneath destitution line and a poor open division instruction framework CDL will undoubtedly increment except if quick advances are engaged to shorten the issue. CDL is realized together in tip top and non-world class homes and henceforth its developing inescapability. Domestic Child Labor dwindling 
under the particular circumstances depicted in ILO Convention No.182 is measured inside the Worst Forms of Child Labor (WFCL). Anyway in Pakistan it has not been recognized as a worst structure in the rundown of 29 perilous kinds of WFCL (add). This is for the most part because of the frame of mind of social acknowledgment of this type of child labor whereby bosses consider and see it as a demonstration of consideration, however no alleviation including training openings and amusement are obtainable to these children (Sadruddin, 2011). This communal acknowledgment to $\mathrm{CDL}$ as an 'altruistic' demonstration to check 'neediness' intensifies the issues and brands intercessions hard to execute and furthermore to continue. In addition grown-up domestic labor is relieved with CDL that is unquestionably increasingly reasonable and certainly less expensive. An incredible correspondence procedure for CDL in Pakistan need to be considered in total relations of infringement, that have a penchant to change from low power maltreatment to great force brutality(Fassa, Facchini, Dall'Agnol, \& Christiani, 2000).

Anyway substantial number of children from age five to fifteen is observed to be engaged with domestic child labor in Pakistan. As indicated by the overview of Federal Bureau of Statistics in 1996, all out number of children laborers is 3.3 million. Tragically these children are presented to perilous working conditions having no entrance to fundamental human needs like wellbeing, instruction and different offices (Chaudhary \& Khan, 2002). Child Domestic Labor (CDL) is additionally one of the worst sorts of child labor. Indeed, wonder of Child Domestic Labor (CDL) is that of the imperceptible type of child labor (Federal Bureau of Statistics 1996).

\section{Objectives of the Study}

1. To study the Socio-economic characteristics of respondents.

2. To highlight the problems faced by child domestic labor.

3. To offer recommendations to overcome the issue of child domestic labor.

\section{Literature Review}

Child domestic laborers (for example children in domestic labor) are individuals younger than 18 who work in families of individuals other than their nearest family doing domestic tasks, thinking about children, consecutively shops and in some cases serving the business to run private ventures from home (Parreñas, 2000). This incorporates children who are paid for their work, just as the individuals who are not paid or who get in kind advantages, for example, sustenance and sanctuary (Labor, 2004). Child domestic specialists involve the biggest populace of transient. They are likewise for the most part young ladies. Children as youthful as seven years of age are routinely squeezed into domestic administration, and notwithstanding would like actually, most are denied of the chance to go to class. Child domestic laborers are secluded from their families and from chances to make companions and are under the absolute control of businesses who don't really have their best enthusiasm as an essential concern (Blagbrough, 2008). 
Child domestics are children who are engaged with work as housemaids, babysitters, house-young men or 'pony young men's inside private family units. Young ladies are employed to do family unit tasks. The protection of the work makes them imperceptible laborers. Their dispersal among different family units, the absence of lawful acknowledgment for the work, its nonappearance from precise research, and from official insights, all consolidate to fortify its intangibility (Akhtar \& Razzaq, 2005). The passive consent of general society everywhere to the work in Pakistan is by all accounts as a result of customary socialization, which gives the feeling that domestic work is ladies' predetermination; something that they were destined to do and in this way, domestic work can't be hurtful to children. Some will in general view it as a superior option in contrast to poverty and dejection, and in this way businesses are playing out a social commitment (Bryant, 2010).

The issue of child domestic labor is extremely perplexing and hazardous. Domestic child laborers are among the most imperceptible child laborers. The quantity of children abused in private family units is obscure as a result of the concealed idea of the work(Basu, 2000). A considerable lot of these children are young ladies and in numerous nations domestic administration is viewed as the main business choice a young lady may have. Children misused in domestic administration are paid close to nothing or nothing, are malnourished, are truly helpless against further maltreatment and abuse, and don't go to class (UNICEF., 2005). In any case, since child domestic specialists are utilized inside a casual family condition, they can't be coordinated as a professional gathering inside conventional working frameworks on the grounds that such reconciliation would assume an acknowledgment of the possibility of child domestic labor. In the meantime, without lawful activities, it is hard to battle child domestic labor. Moreover, the terms, standards and gauges to control the work of children are missing in light of the fact that children work in a to a great extent undetectable space outside law and the open circle and their domestic labor can't be incorporated under typical labor laws(Devereux \& Sabates-Wheeler, 2004).

One essential motivation behind why child domestic labor is considered so risky is on the grounds that powerless children are set in a work environment another person's home that remaining parts avoided general visibility or any type of labor reviews. A huge number of family units around our very own nation don't mull over utilizing youthful children to work in their homes. One considers what number of families utilizing children remember such preconditions, including the guideline expressing that by no means should children younger than 14 be employed as laborers (Hungerland, 2007). A huge pay distinction between the child laborer and another talented laborer is generally in charge of child labor, and a similar motivating force appears to remain constant for domestic child labor. Realize that poverty might be a noteworthy reason for child labor, however poverty is additionally brought about by child labor(Edmonds \& Pavcnik, 2005). A child who neglects to go to class will finish up working in modest occupations without adapting any significant aptitudes for his entire life and will thus stay poor. In any case, there is adequate motivation to trust that the marvel of domestic child labor won't finish individually accord at any point in the near future (Matsuno \& Blagbrough, 2006). 
According to Federal Bureau of Statistics (1996) In Pakistan expansive number of children from age five to fifteen is observed to be associated with domestic child labor. As per the study of Federal Bureau of Statistics in 1996, complete number of children specialists is 3.3 million. Tragically these children are presented to perilous working conditions having no entrance to fundamental human needs like wellbeing, instruction and different offices. Child Domestic Labor (CDL) is likewise one of the worst sorts of child labor. Truth be told, marvel of Child Domestic Labor (CDL) is that of the imperceptible type of child labor (Ghayur, 1996).

As per ILO in South Asia, child domestic labor (CDL) is socially acknowledged and usually polished. CDL alludes to circumstances where children are locked in to perform domestic undertakings in the home of an outsider or business. Where child domestic labor is exploitative and incorporates dealing, servitude, or practices like bondage, or work which, by its temperament or the conditions in which it is done, is perilous and prone to hurt the wellbeing, security, or ethics of the child, it establishes a worst type of child labor as characterized in the International Labor Organization (ILO) Worst Forms of Child Labor Convention (No. 182) (Boateng, 2017).

In accordance domestic service is an important source of wage employment for unskilled women and children belonging to low income households in urban areas. The majority of domestics have no special skill or training apart from experience gathered in the household or in their own homes (Kaur, 2007). Women and children worker in this sector, usually employed in poorly paid menial jobs such as sweeper, wane women and maids, are not protected by any contractual obligation, their service is insecure and possibilities of exploitation are high as there is usually no limit to hours of work. Working hours can be exceedingly long for domestic workers residing in the employer's house since they undertake all types of household's duties (Weiner, 2016). While the extent of women's employment in domestic service is not known, however some insight into their economic situation is provided by a survey of 680 working women in Karachi including 470 women in low income occupation of factory workers, home based workers and women who worked outside the home in the informal sector mainly as domestic servants. The findings indicate that domestic servants were the most economically vulnerable group. Their monthly wages earnings of home based workers. However, in terms of total household income they belonged to the poorest families. The importance of women's earning to family income was especially marked in the case of this group where on average their income comprised more than half of total household earning. The majority would have preferred to work in formal sector either in factories or in government organizations but their lack of education and knowledge of job opportunities relegated then to the least preferred option of domestic service (Galli, 2001).

Domestic work is often viewed as a part in which laborers are very helpless against pressure and misuse. Domestic work has included unpredictability that the working environment is somebody's home, not normal for work that happens in a perceived "work environment" condition, domestic administration happens in a situation that is probably 
going to be set apart by very customized relations among business and worker(De la Luz Ibarra, 2000). Formal laws, just as casual social standards administering manager, worker relations, may have less essentialness than customary and comfortable standards of conduct within the private area (Javaid et al., 2011). The labor in undocumented and untaxed, it is outside the domain of the state. The authoritative understanding, quite often between the business and the worker or managers family, is unwritten, non-official and vigorously onesided for the business. Domestic administration is just accessible to the first class of a given network, be it a town, town or urban neighborhood and the specialist organizations are among the least fortunate and most helpless in rustic and urban culture domestic laborers close have no instruction and make no venture to enter this profession and the abilities required to perform it successfully require no formal preparing (Mantouvalou, 2006).

According to the report girl domestic servants have not yet been able to become the center of attention and recognition. A little is known and discovered about this segment of child labour population which is usually dominantly influenced by the male members of the family. In spite of hard work and labour they are not provided even sufficient food, education, health and general care in the family (Lobstein, Baur, \& Uauy, 2004). On the other hand, girl domestic servants in the household employment are entirely at the mercy of the householder and granted no security or protection(Anderson, 2000). Die socio economic circumstances of the families having more girls force this vulnerable group of seed financial assistance under any conditions. Subjugation of the girl within family due to boy importance in some instances and lack of educational facilities and selfishness of the parents, sometime pave the way for domestic labour. Migration from rural areas to the cities, growth of "Katchi Abadies" and slums with increased population and large family size as well as limited resources and insufficient support by male children, force families to put their female children in to vulnerable situation for economic gains. Although work performed to earn a living is justified for girls whose relatives are not in a place to aspect afterward them due to certain reasons but it may interfere with their normal development and their earnings would be insufficient to support themselves and their families. Girl domestic servants are supposed to have no feelings, recognition and requirements by the employers and as a result of differential treatment from the children of the household, they suffer from a number of emotional and psychological problems(Hines, Brown, \& Dunning, 2007). They feel unhappy, tired and depressed all the times, have frequent headaches, eating, sleeping problems, and lose interest in playing etc. Girl domestic servants, staying with their employer, leaving familiar home environment, may find more emotional problems than those who are living with their families (Lopez, 2006).

\section{Research Methodology}

Methodology is an understanding of obvious principles and systems on which research is rooted and beside that assert for wisdom are evaluated. The idea, structures, tackles and procedures that are used to contemplate scientific scholars are allude as reasonable technique. Methodology fundamentally offers a rule for the researcher whereas conducting the research and moreover fills in as instrument for the measurement of latest information. The present study was quantitative in nature. The universe of the study was Quetta city. 
The target population of the study was domestic workers under the age of 18 years. In the study a sample size of 120 respondents was drawn through snowball sampling technique. Out of total respondents, 60 male and 60 female respondents were selected. In the present study, the data was collected with the help of interview schedule because domestic child might not be able to read and understand the questions themselves. The data were analysis through Statistical Package for Social Sciences (SPSS).

\section{Result and Discussion}

\section{Age of The Respondents}

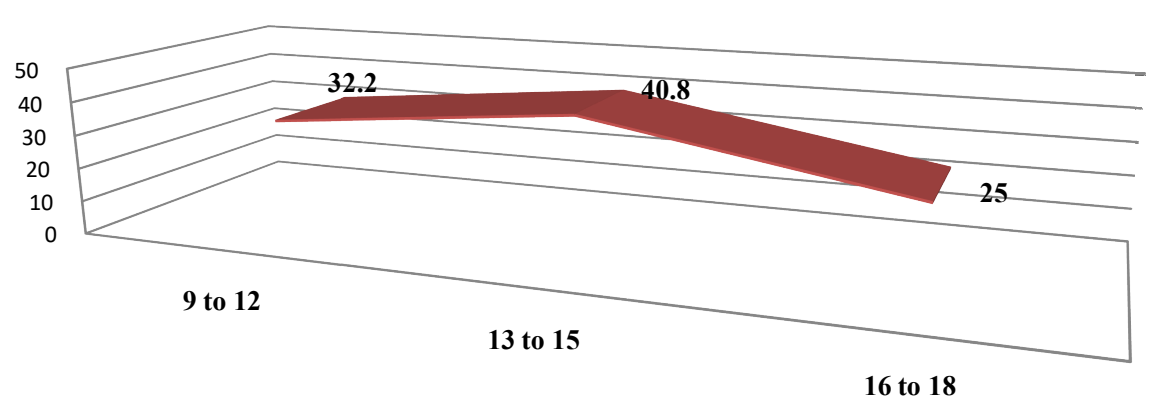

Figure 1 show the age of the respondents. Data displays that $40.8 \%$ of the subjects of the study were in the age group of 13 to 15 years while $32.2 \%$ of the subjects of the study were in the age group of 9 to 12 years. Data further shows that $25 \%$ of the subjects of the study were in the age group of 16 to 18 years.

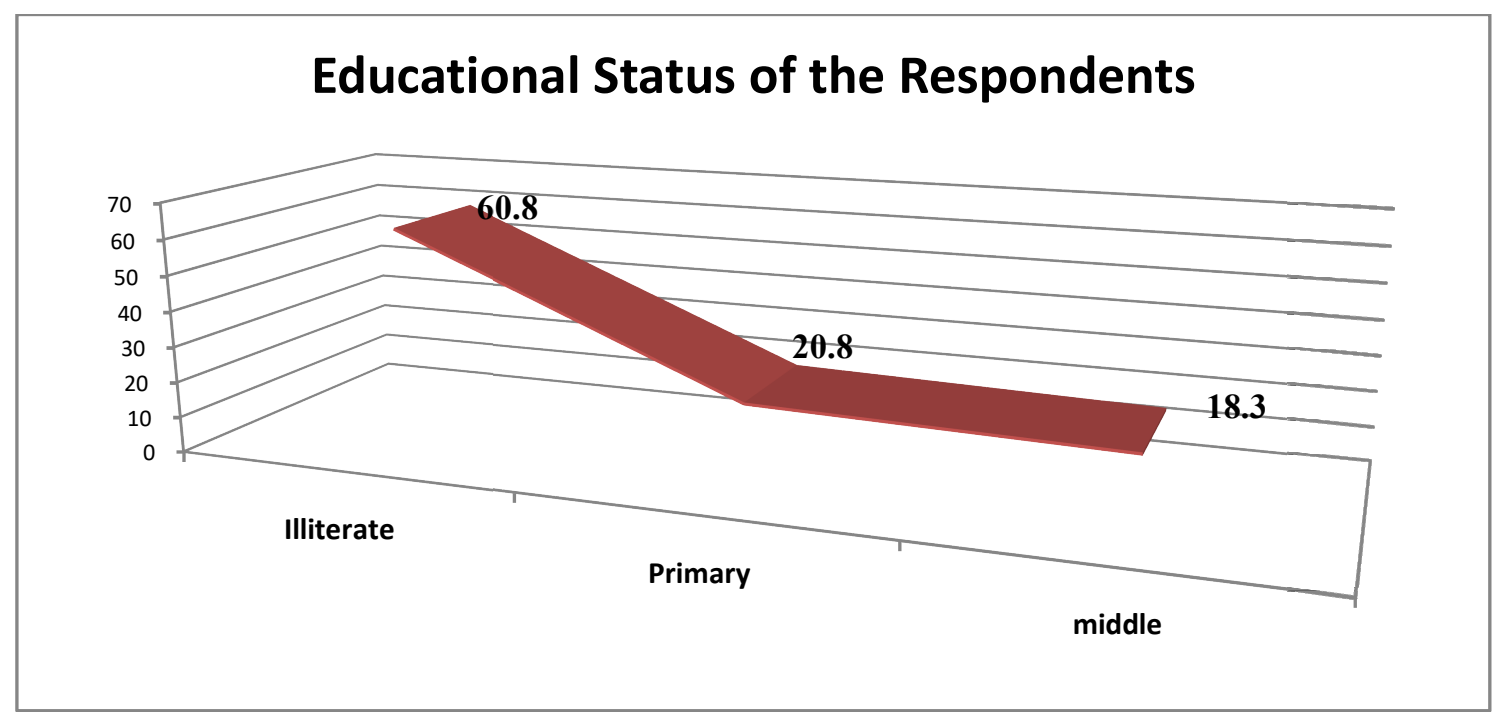


Figure 2 Shows the Educational Status of the subjects of the study. Data shows that majority $60.8 \%$ of the subjects of the study were Illiterate where as $20.8 \%$ of the subjects of the study were having Primary education. Data further shows that $18.3 \%$ of the subjects of the study were having Middle education.

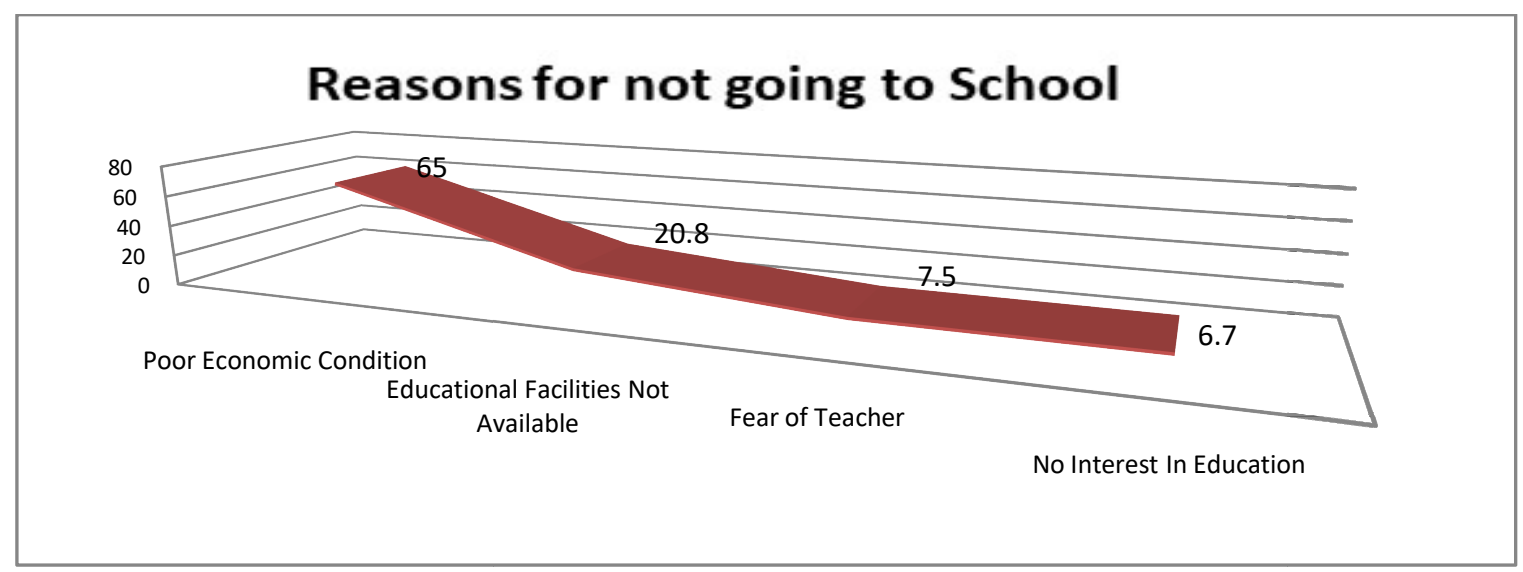

Figure 3 Shows data regarding the reasons for not going to school. Data shows that majority $65 \%$ of the respondent was not going to school due to poor economic condition while $20.8 \%$ of the respondents were not going to school due to the unavailability of educational facilities. Data further shows that $7.5 \%$ of the respondents were not going to school due the fear of teacher where as $6.7 \%$ of the respondents were not going to school due the lack of interest in education.

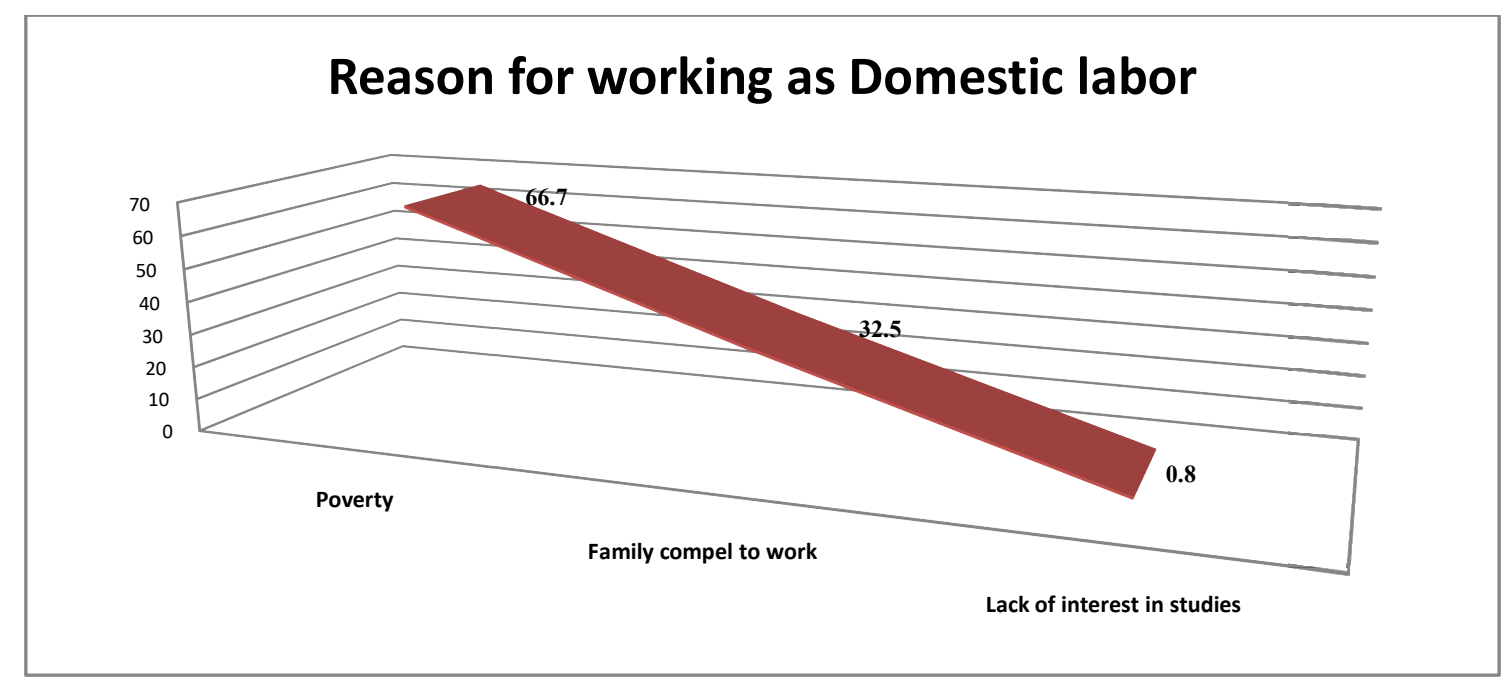

Figure 4 Shows data regarding the reason for working as domestic labor. Data illustrates that majority $66.7 \%$ of the subjects of the study were working as domestic labor due to 
poverty while $32.5 \%$ of the subjects of the study were working as domestic labor due to compulsion of their family. Data further shows that only $0.8 \%$ of the subjects of the study working because of lack of interest in studies.

Association between the age of the respondents and Average monthly income of respondents

\section{Daily working hours of the respondents}

\begin{tabular}{|c|c|c|c|}
\hline & Observed N & Expected N & Residual \\
\hline $3-4$ & 31 & 40.0 & -9.0 \\
\hline $4-5$ & 50 & 40.0 & 10.0 \\
\hline $6-7$ & 39 & 40.0 & -1.0 \\
\hline Total & & & \\
\hline & 120 & & \\
\hline
\end{tabular}

Average monthly income of respondents

\begin{tabular}{|c|c|c|c|}
\hline & Observed N & Expected N & Residual \\
\hline $500-1000$ & 2 & 19.8 & -17.8 \\
\hline $1001-1500$ & 14 & 19.8 & -5.8 \\
\hline $1501-2000$ & 32 & 19.8 & 12.2 \\
\hline $2001-2500$ & 26 & 19.8 & 6.2 \\
\hline $2501-3000$ & 40 & 19.8 & 20.2 \\
\hline ABOVE 3001 & 5 & 19.8 & -14.8 \\
\hline Total & 119 & & \\
\hline
\end{tabular}

\section{Test Statistics}

\begin{tabular}{|c|c|c|}
\hline & Daily Working Hours & $\begin{array}{c}\text { Average monthly income of } \\
\text { respondent }\end{array}$ \\
\hline Chi-Square & 4.550 & 58.731 \\
\hline DF & 2 & 5 \\
\hline Significance Level & .103 & .000 \\
\hline
\end{tabular}

A 0 cells $(.0 \%)$ have expected frequencies less than 5 . The minimum expected cell frequency is 40.0 .

b0 cells $(.0 \%)$ have expected frequencies less than 5 . The minimum expected cell frequency is 19.8 .

Majority $(41.7 \%)$ of the respondents were working 4 to 5 hours daily, $32.5 \%$ of the respondents were working 6 to 7 hours and $25.8 \%$ of the respondents were working 3 to 4 hours daily. 
Majority (33.3\%) of the respondents' monthly income was 2501 to 3000 rupees, $26.7 \%$ of the respondents' monthly income was 1501 to 2000 rupees, $217 \%$ of the respondents' monthly income was 2001 to $2500,11.7 \%$ of the respondents monthly income was 1001 to 1500 rupees, $4.2 \%$ of the respondents monthly income was above 3000 rupees and $1.7 \%$ of the respondents monthly income was 500 to 1000 rupees.

\section{Conclusions}

Domestic child labour in Pakistan is a thoughtful problem that desires immediate solution. Children working as domestic labour in Quetta mostly belong to poor socio-economic background. Most of them were from rural zones of the Balochistan. They are illiterate, untrained children who don't have any other choice of employed. Most of the respondent's parents were illiterate and doing daily wages job and their salaries do not fulfill the expenditure of their houses so their children were doing such type of jobs. Some of the children were employed in three to four houses because of less payment from the employer though several of them were working full time in one house. Most of they don't the facility of their own house so it is very difficult for them to pay the rent of house. Although they belonged to deprived families some of them were forced to work as domestic labour.

The findings of the study also shows that child domestic labour has also low salary even not paid the salary in time. They are doing different type of task at house of employer. Several of them are working 6 to 7 hours daily. They are completely on the sympathy of their employer. Several of them are not allowed a single holyday in month throughout the work. They do all type of boring, difficult and unwanted works in the employers' house. Domestic child labour is often victims of physical and psychological abuse form their employer. Mostly employers have rude behavior if they commit mistake and majority of the domestic labour are verbally because of invisibility of the workers no one in the society. It is fact that no one in the society gives respect to domestic labour because of their poor family background. The findings of the study are also supported by literature review as mention in the above literature that poor socio- economic family background of the respondents and level of education are associated with child domestic labour.

\section{Recommendations}

The basic purpose of the study is to acquire knowledge regarding domestic child labour to focus their problems and suggest phases for the solution of the problems of domestic child labour that need immediate actions.

$>$ Child labour is one of the severe types of social exploitation it need to be forbidden.

$>$ Pakistan had signed the ILO charter which prohibits the employment of children in hazardous work and also regulate the circumstances of work in convinced other employment where the employment is not prohibited it is essential be tilled exactingly. 
Establishment of free and compulsory education and beginning fences to girls education. Bothe male and female children should be assumed equal chances of receiving education.

$>$ Raising public awareness to tackle child labour in all level of the humanity. There should be community consciousness criticize in public level.

\section{References}

Akhtar, S., \& Razzaq, S. (2005). Child Domesftic Labour in Pakistan: Overview, Issues and Testable Hypothesis. Center for Research and Poverty Reduction and Income Distribution, pp.1-24.

Alderson, P. (2008). Young Children's Rights: Exploring Beliefs: Jessica Kingsley Publishers.

Ali, M., Shahab, S., Ushijima, H., \& de Muynck, A. (2004). Street Children in Pakistan: A Situational Analysis of Social Conditions and Nutritional Status. Social Science \& Medicine, vol.59:8, pp.1707-1717.

Basu, K. (1999). Child Labor: Cause, Consequence and Cure, with Remarks on International Labor Standards. Journal of Economic Literature, vol.37:3, pp.1083-1119.

Blagbrough, J. (2008). Child Domestic Labour: A Modern Form of Slavery. Children \& Society, vol.22:3, pp.179-190.

Boateng, P. (2017). Interventions on Child Labour in South Asia. UK: Brighton.

Bryant, D., Seigle, D., Jabber, L., \& McGeorge, N. (2010). Mediating Criminal Domestic Violence Cases: How Much is too Much Violence. International Perspectives in Victimology, vol.5:1, pp.47-54.

Chaudhry, M. A., \& Khan, F. N. (2002). Economic and social determinants of child labor: A case study of Dera Ismail Khan, Pakistan. Lahore Journal of Economics, vol.7:2, pp.15-40.

d'Souza, A. (2010). Moving towards decent work for domestic workers: An overview of the ILO's work: ILO.

Dennis, M. J. (1999). The ILO convention on the worst forms of child labor. American Journal of International Law, vol.93:4, pp.943-948. 
Devereux, S. \& Wheeler, R. S. (2004). Transformative Social Protection. Institute of Development Studies Brighton, Sussex BN1 9RE England.

Edmonds, E. V. \& Pavcnik, N. (2005). Child Labor in the Global Economy. Journal of Economic Perspectives, vol.19:1, pp.199-220.

Fassa, A. G., Facchini, L. A., Dall'Agnol, M. M. \& Christiani, D. C. (2000). Child Labor and Health: Problems and Perspectives. International Journal of Occupational and Environmental Health, vol.6:1, pp.55-62.

Galli, R. (2001). The Economic Impact of Child Labour (Vol. 128). Geneva: International Institute for Labour Studies.

Ghayur, S. (1996). Labour Market Issues in Pakistan: Unemployment, Working Conditions and Child Labour. The Pakistan Development Review, vol.35:4, pp.789-803.

Gulrez, F. (2006). The State of Pakistan's Children, (Islamabad: SPARC Society for the Protection of the Rights of the Child, 2007), p.50.

Hines, D. A., Brown, J. \& Dunning, E. (2007). Characteristics of Callers to the Domestic Abuse Helpline for Men. Journal of Family Violence, vol.22:2, pp.63-72.

Hungerland, B. (2007). Working to be Someone: Child Focused Research and Practice with Working Children: Jessica Kingsley Publishers.

Javaid, Z., Arshad, M. \& Khalid, A. (2011). Child Protection in Disaster Management in South Asia: A Case Study of Pakistan. South Asian Studies, vol.26:1, p.191.

Kaur, A. (2007). International Labour Migration in Southeast Asia: Governance of Migration and Women Domestic Workers. Intersections: Gender, History and Culture in the Asian Context, 15, 2007.

Labour, I. P. o. t. E. o. C. (2004). Helping Hands Or Shackled Lives?: Understanding Child Domestic Labour and Responses to it: International Labour Organization.

Lobstein, T., Baur, L. \& Uauy, R. (2004). Obesity in Children and Young People: A Crisis in Public Health. Obesity Reviews, vol.5, pp.4-85.

Lopez, S. H. (2006). Emotional Labor and Organized Emotional Care: Conceptualizing Nursing Home Care Work. Work and Occupations, vol.33:2, pp.133-160.

Maia, R. C. \& Cal, D. (2014). Recognition and Ideology: Assessing Justice and Injustice in the Case of Child Domestic Labor. Journal of Political Power, vol.7:1, pp.63-85. 
Mantouvalou, V. (2006). Servitude and Forced Labour in the 21st Century: The Human Rights of Domestic Workers. Industrial Law Journal, vol.35:4, pp.395-414.

Matsuno, A., \& Blagbrough, J. (2006). Child Domestic Labour in South-East and East Asia: Emerging Good Practices to Combat It: International Labour Office.

Parreñas, R. S. (2000). Migrant Filipina Domestic Workers and the International Division of Reproductive Labor. Gender \& Society, vol.14:4, pp.560-580.

Sadruddin, M. M. (2011). Study on the Important Issues of Child Rights in Pakistan. Dialogue, vol.6:1, p.14.

Tampubolon, L. H. \& Sirait, G. M. (2012). Assessment on Monitoring Mechanism to Stop Employment of Children as Domestic Workers in Jakarta and its Surroundings. Jurnal Perkotaan, vol.4:1, pp.28-49.

Thompson, B. (1992). Africa's Charter on Children's Rights: A Normative Break with Cultural Traditionalism. The International and Comparative Law Quarterly, vol.41:2, pp.432-444.

UNICEF. (2005). The State of the World's Children 2006: Excluded and Invisible: Unicef.

Van Walsum, S. (2011). Regulating Migrant Domestic Work in the Netherlands: Opportunities and Pitfalls. Canadian Journal of Women and the Law, vol.23:1, pp.141-165.

Weiner, L. (2016). From Working Girl to Working Mother: The Female Labor Force in the United States, 1820-1980: UNC Press Books.

Working, P. (2008). Legislative Reform On Child Domestic Labour: A Gender Analysis. UNICEF.

Dr. Sadia Barrech is an Assistant Professor in the Department of Social Work, University of Balochistan.

Muhammad Din is Research Scholar in the Department of Sociology, International Islamic University Islamabad.

Allauddin is Ph.D Scholar in the School of International Relations and Public Affairs, Shanghai International Studies University China. 